\title{
Removal of granulosa theca cells tumor in the mare
}

\author{
Amrozi $^{1,2, *}$, R. Harry Soehartono ${ }^{1}$, Erly Rizka Adistya ${ }^{3}$, Iga Mahardi ${ }^{2}$, Hidayati Mukarromah $^{2}$, \\ M. Ibnu Satria ${ }^{2}$, Ho Kin $\mathrm{Wai}^{4}$, Sugganya a/p Ravi ${ }^{4}$ \\ ${ }^{1}$ Department of Clinic, Reproduction, and Pathology, Faculty of Veterinary Medicine, IPB University \\ ${ }^{2}$ Dr Am Veterinary Services, Jl Ketimun C93, Sinarsari, Dramaga, Bogor \\ ${ }^{3}$ Veterinary Teaching Hospital, Faculty of Veterinary Medicine, IPB University \\ ${ }^{4}$ Program of Veterinary Profession Education, Faculty of Veterinary Medicine, IPB University
}

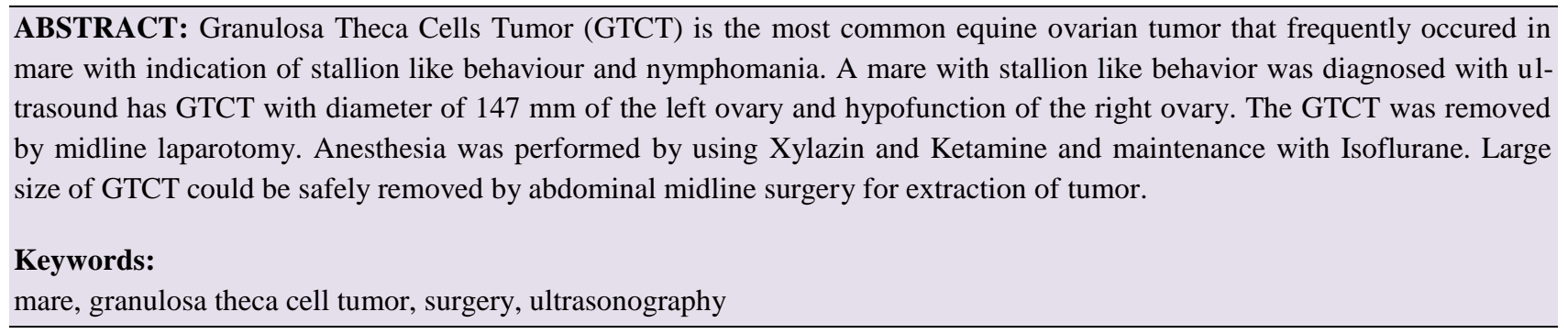

\section{- INTRODUCTION}

Granulosa Theca Cells Tumor (GTCT) are the most common equine ovarian tumor that frequently occur to older mares with indication of stallion like behaviour and nymphomania (Harper et al. 2010, Nielsen and Moulton 1990). There are no definitive diagnostic test for GTCTs in horses, clinical founding occur while performing rectal palpation, serum hormone analysis, and ultrasonographic examination (Christman 1999). Indication of GTCT by serum hormone anaylsis are shown having exponentially elevated inhibin hormone and increase of testosterone hormone (McCue et al. 2006, Troedsson et al. 2003). It is thought that high inhibin levels are responsible for a lack of ovarian activity on the contra lateral ovary. Generally, the treatment of GTCT conducted through surgery (Kottarathil et al. 2013).

\section{- CASE}

Anamnese: the brown color mare named Djulhizah, age 4 years old, sex female, and weight $450 \mathrm{~kg}$. Clinical symptoms: aggressive stallion like behaviour and anoestrus, does not get pregnant after many trials of natural mating. Physical examination: heart rate 40 times/minute, respiratory rate 20 times/minute, and body temperature $38.0{ }^{\circ} \mathrm{C}$. Diagnosis: a large hard mass at the left ovary was found by rectal palpation. By ultrasound diagnostic was confirmed that hard mass was GTCTs that measures a diameter of $147 \mathrm{~mm}$ of the left ovary and hypofunction of the right ovary (Fig. 1). Prognosis: fausta. Treatment: The GTCT was decided to remove by midline laparotomy due to the large size of tumor.

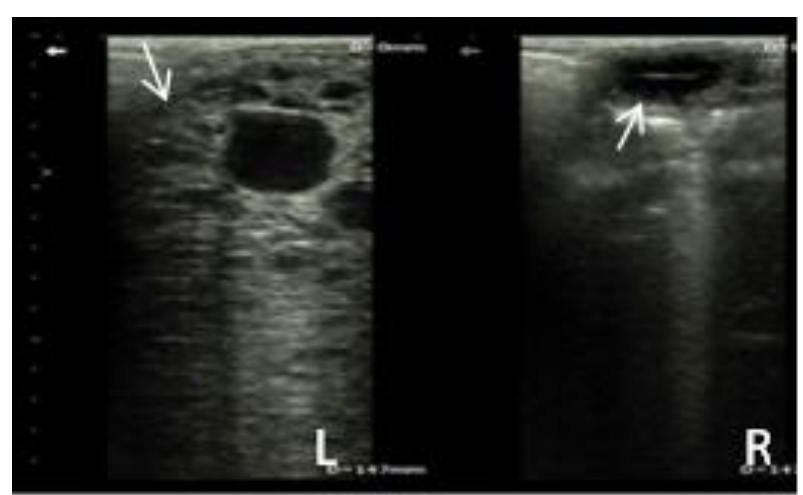

Figure 1. Ultrasonography images of the ovaries in a granulosatheca cell tumor (GTCT). The GTCT appear as a multicystic structure with dense areas (L). The inactive right ovary appears as a small hypoechoic structure (R).

\section{- SURGERY}

Anaesthesia was performed by using a combination of Xylazin $(0.5$ to $1 \mathrm{mg} / \mathrm{kg} \mathrm{IV})$ and Ketamine $(0.5 \mathrm{mg} / \mathrm{kg}$ IV) and maintenance with Isoflurane. The abdomen was cleanly shaved and disinfected. Incision was performed at abdominal midline to avoid vascularization and to avoid any nerve that will cause permanent damage or bleeding out of mare (Fig. 2). Mayo blunt dissecting scissors were used to perforate the peritoneum and to enlarge the opening abdominal cavity. Once the abdominal cavity was opened, a gloved hand was introduced into the peritoneal cavity and

Received: 07-01-2020 | Revised: 05-02-2020 | Accepted: 10-02-2020

(c) 2020 CC-BY-SA. This is an Open Access article that is distributed under the terms of Creative Commons Attribution ShareAlike 4.0 International License (https://creativecommons.org/licenses/by-sa/4.0/). 
extended in a caudal direction to locate the GTCT. Another gloved hand has to retain pressure at the abdomen to avoid intestine spillage cause by peristaltic movements. The GTCT was then exteriorized through the incision. Multiple ligations of the GTCT pedicle were performed with silk. Once ligation was complete, the GTCT pedicle was transected distal to the ligatures, the GTCT was removed, and the pedicle were examined carefully for hemorrhage. It was measured at $15 \mathrm{~cm}$ in diameter and had a firm consistency. The peritoneum and abdominal muscles were then sutured, then the linea alba, along with the subcutaneous layer, and last the skin. All sutures performed were the mattress suture, to ensure a secure and firm grip of the incisions. The peritoneum and linea alba were closed with mattress suture. The skin was closed with simple interrupted suture to ensure a secure and firm grip of the incisions.
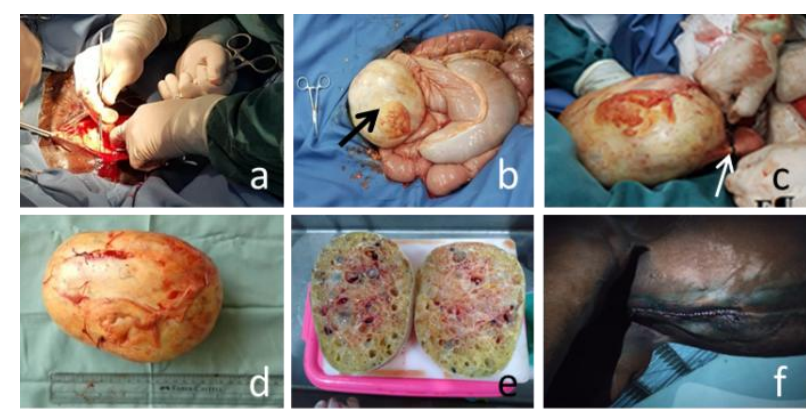

Figure 2. Mare undergone tumor extraction: preparation of medial abdomen (a), fixation of tumor (b), multiple ligation towards tumor to avoid haemorrhage (c), the length of tumor is $14.5 \mathrm{~cm}$ and width of tumor $12.5 \mathrm{~cm}(\mathrm{~d})$, dissection of the tumor (e), simple interrupted suture to close the skin (f).

Postoperative treatment was administrated with antibiotics, glucocorticoid, and non-steroid antiinflammatory drug (NSAID). Gentamycin (GENTA-JECT ${ }^{\circledR}$ $10 \% 0.01 \mathrm{mg} / \mathrm{mL}$ ) of $15 \mathrm{~mL}$ twice a day for 5 days, Flunixinmeglumine (FORTIS ${ }^{\circledR} 0.5 \mathrm{mg} / \mathrm{mL}$ ) of $10 \mathrm{~mL}$ twice a day for 5 days, and Dexamethasone (RHINDEXSA ${ }^{\circledR} 0.02$ $\mathrm{mg} / \mathrm{mL}$ ) of $10 \mathrm{~mL}$ twice a day for 5 days. Dexamethasone is a glucocorticoid that can act as an anti-inflammatory and reduce postoperative pain (Waldron et al. 2013). The incision site was given an apathetic ointment topically and sprayed with Limoxin-25 Spray (INTERCHEMIE ${ }^{\circledR}$ ) that acts as an antiseptic. The mare showed progressive signs of recovery and shows no abnormal behaviours. Mare have high food intake and show no sign of complication after surgery. After 14 days the mare was given back to the owner in a healthy condition and there was no further complain from the owner.

\section{- CONCLUSION}

Large size of GTCT could be safely removed by abdominal midline surgery for extraction of tumor.

\section{- AUTHOR INFORMATION}

\section{Corresponding Author}

*A: amrozi217@gmail.com

Department of Clinic, Reproduction, and Pathology, Faculty of Veterinary Medicine, IPB University. Jl. Raya Dramaga, Kampus IPB Dramaga, Bogor, Jawa Barat - Indonesia 16680

\section{- REFERENCES}

Christman SA, Bailey MT, Wheaton JE, Troedsson MH, Ababneh MM, Santschi EM. 1999. Dimeric inhibin concentrations in mares with granulosa-theca cell tumors. American journal of veterinary research. 60(11):1407-1410.

Harper J, Stewart AJ, Kuhnt L, Waguespack RW, Holland M, Downs C. 2010. Ultrasonographic appearance and abdominal haemorrhage associated with a juvenile granulosa cell tumor in a foal. Equine Veterinary Education. 22(3): 115-120.

Kottarathil VD, Antony MA, Nair IR, Pavithran K. 2013. Recent advances in granulosa cell tumor ovary: a review. Indian Jurnal of Surgery Oncology. 4(1): 37-47

McCue PM, Roser JF, Munro CJ, Liu IK, Lasley BL. 2006. Granulosa cell tumors of the equine ovary. Veterinary Clinics: Equine Practice. 22(3): 799-817.

Nielsen SW, Moulton JE. 1990. Tumors of the ovary. In: Tumors in domestic animals, 3rd ed., University of California Press, Berkeley, CA. pp. 504- 507 .

Troedsson MHT, McCue PM, Macpherson ML. 2003. Clinical aspects of ovarian pathology in the mare. Pferdeheilkunde 19(6): 577.

Waldron NH, Jones CA, Gan TJ, Allen TK, Habib AS. 2013. Impact of perioperative dexamethasone on postoperative analgesia and sideeffects: systematic review and meta-analysis. British journal of anaesthesia.110(2):191-200. 